\title{
Out-of-Class Activities Employed by Successful and Unsuccessful English Department Students
}

\author{
Cayandrawati Sutiono $^{1)^{*}}$, Ali Saukah ${ }^{2)}$, Suharmanto ${ }^{2)}$, Monica D.D. Oka ${ }^{2)}$ \\ ${ }^{1)}$ English Language Education, FKIP-Universitas Lambung Mangkurat \\ ${ }^{2}$ Department of English-Universitas Negeri Malang \\ Jl. Brigjen H. Hasan Basri No.87, Pangeran, Banjarmasin Utara, Kota Banjarmasin, South Kalimantan 70123. \\ E-mail: sutionocayandrawati@gmail.com*
}

\begin{abstract}
This study aims at exploring the out-of-class activities employed by the successful and unsuccessful students of the English Department. The activities involve out-of-class general activities and out-of-class English learning activities. The general activities are categorized into academic activities, social activities, leisure activities, and part-time jobs, while the English learning activities are Self-Instruction, Naturalistic Language Learning and Self-Directed Naturalistic Language Learning. This study is qualitative in nature. It was done through (1) documents analysis, (2) in-depth interviews done one by one with the participants.
\end{abstract}

Key Words: out-of-class activities, out-of-class general activities, out-of-class English learning activities, successful students, unsuccessful students

\begin{abstract}
Abstrak: Penelitian ini bertujuan untuk menelusuri aktivitas pembelajaran di luar kelas yang dilakukan oleh mahasiswa Jurusan Bahasa Inggris yang sukses dan tidak sukses. Aktivitas tersebut terdiri dari aktivitas umum dan aktivitas pembelajaran Bahasa Inggris. Pada aktivitas umum terdiri dari aktivitas akademis, aktivitas sosial, aktivitas santai, dan pekerjaan paruh waktu, sedangkan aktivitas pembelajaran Bahasa Inggris adalah pembelajaran diri, Pembelajaran Bahasa Naturalistik, dan Pembelajaran Bahasa Naturalistik Acu Diri. Penelitian ini merupakan penelitian dengan rancangan kualitatif. Penelitian ini dilakukan melalui (1) analisis dokumen, (2) wawancara mendalam satu persatu dengan responden.
\end{abstract}

Kata kunci: pembelajaran di luar kelas, aktivitas umum, aktivitas pembelajaran bahasa inggris, mahasiswa yang sukses, mahasiswa yang tidak sukses

The English Departments are the institutions that are expected to improve the quality of future English teachers. Actually, the improvement of student achievement has always been one of the main goals of education including the main goal of English Education. The poor mastery of English and the students' low achievement is partly due to the training the teachers got from the universities they attended.

In facing this situation, the English Departments need to look at the conditions of the students they have. As we know, people are unique. None have the same characteristics and qualities. This is true for the students of the English Departments. The institutions, in this case the Department of the National Education, have tried to select the potential students based on their expected levels of performance through the Na- tional Examination (SNMPTN). Selected by this examination, the accepted students are expected not to face difficulties when they are in the program. Contrary to expectations, however, students of the English Departments show different qualities in their performance as shown by their GPAs. There are a few students who perform well and at the same time there are others who are having problems in following the lessons given. Although the students of the English Department are selected and admitted through the same national entrance test, follow the same instruction which uses the same syllabus, taught by the same lecturers, and get the same materials and treatments in the same classroom, they show a different performance.

The success of learning is the responsibility of the students. Success depends on the learner's capaci- 
ty to create and take advantage of naturalistic learning situations. Some individuals are more successful than others in mastering the language and some individuals learn some aspects of language more easily than others. The success of second language learning will be the result of how learners invest their time, attention and energy in comprehending and producing the target language. Learning of any language skill involves the investment of one's time and efforts in learning. Brown (2001) confirms that successful mastery of the second language will be due to a learner's own personal "investment" of time, efforts, and attention to the target language in the form of a battery of strategies for comprehending and producing the language.

Many factors influence achievement. Not only factors that come from instruction, but also factors that are brought by the students from outside the classroom. Oxford et al. (1993) have studied factors affecting achievement. According to them there are six factors which are relevant to achievement in learning a new language. They are motivation, language learning styles, language learning strategies, gender, course lev$\mathrm{el}$, and previous experience in learning a foreign language.

Various studies (Fathman, 1976; Madrid, 1995; Freeman, 1999; Gan et al., 2004; Bouageune, 2008; Oxford et al., 2009) have been carried out to understand factors which account for low achievement. The causes of low achievement need to be sought as a response toward the conditions of change, such as plans for educational reform, and in response to the particular situation described above.

Learning a new language is something that can take place inside or outside of the classroom. Learning and personal development during the undergraduate years occurs as a result of students engaging in both academic and non-academic activities, inside and outside the classroom, and students who expend more efforts in a variety of activities benefit the most intellectually and in the personal development domain. (Astin, 1993)

Out-of-class experiences involve the activities the students do outside the classroom. The activities can be in the form of academic activities, social activities, leisure activities, and part-time jobs activities. These are all out-of-class activities. Among these outof-class activities, out-of-class English learning activities are also employed. Out-of-class English learning activities are the activities which the students employ intentionally and unintentionally to improve their English.
Various different out-of-class activities are available to be chosen by the students. The activities they choose will unavoidably improve their academic performance and their English proficiency. Also, the students' time spent outside the classroom is longer than it is spent in the classroom. Therefore, the students are responsible for choosing the activities they like to do and they feel they need to do. As such, these activities should be considered as important factors that play a role in the success of the English Department students.

Therefore, out-of-class activities employed by the English Department students need to be studied because of the following reasons: (1) there is an increased demand for English as a foreign language in Indonesia but a simultaneous lack of qualified English teachers. This have caused a rising demand of the English Departments for training qualified English teachers; (2) students show different performance in their academic performance although they are taught by the same lecturers, receive the same materials and the same tasks and assignments; (3) there are probably many successful English students due to their activities to learn English outside their classrooms or informal schooling; (4) students spend more time outside the classroom, so that they have more opportunities to improve their English individually outside; (5) not everything can be learnt in the classroom because of limited time and limited resources available. Students have a lot of opportunities outside the classroom to develop what they have learned in-class; (6) awareness and understanding of the role of students' outof-class activities and out-of-class English learning activities on achievement will allow lecturers to provide optimal learning opportunities for all students.

Moreover, there has been much research on successful students done, especially on learning strategies and personal traits, such as motivation and attitude, but there is less research on out-of-class general activities and out- of- class English learning activities of the students, especially in Indonesian context. The studies of the out-of-class activities were done by Brooks (1992) and Suh, Wasanasomsithi, Short, and Majid (1999), who observed that watching television, going to the cinema, listening to music and interacting with native speakers are the major out-of-class activities students do. They stated that out-of-class leisure activities are useful in the development of students' English conversation skills. They advised ESL instructors to help students identify appropriate leisure activities and provide sufficient guidance to students to pre- 
vent the fossilization of bad language habits. Spratt, Humphreys, and Chan (2002) discovered that most activities adult learners engaged in are related to communication and entertainment, such as watching movies and television in English and using the internet. Additionally, Hyland (2004) noted that the activities students do in English are speaking with family members, talking to people in the stores, talking on the phone, speaking with friends, listening to the radio, attending meetings, reading novels, speaking with colleagues, listening to songs, reading newspapers and magazines, watching TV programs, watching videos, surfing the internet, reading academic books, and writing e-mails in ranking order. Pearson (2004) verify what learners do outside of the classroom. The study showed that his informants were most frequently involved in the following five spare time language activities in English: (1) listening to/watching news on radio or TV; (2) studying in the library; (3) reading books, magazines, or newspapers; (4) watching TV programs, videos, or movies; and (5) listening to music or the radio. The findings showed that the participants did out-of-class language learning more for enjoyment and learning than their formal learning. He did conclude that, among other things, learner motivation and awareness were important aspects of out-of-class language learning. Moreover, he found that students' language proficiency was one factor which influenced what type of activities the informants engaged in, and how frequently.

One research on out-of-class language learning was carried out by Ibaddurahman (2012) whose study describes prevalent out-of-class language learning activities employed by 59 senior high school students in Bandung who were grouped into three different groups of learners: poor, mediocre, and high scores. The study finds that the most popular activities are receptive skills of listening and reading, indicating that Indonesian students are largely passive learners of English. It also reveals that there is a correlation between the activities and how they perform in the class.

Based on what the researchers above have done, it can be concluded that first, all of the studies were mostly done in ESL contexts, except the one that was employed in Indonesia; second, the previous studies did not show the impact of the activities toward the students' achievement; third, the previous studies did not cover the genereal out-of-class activities; fourth, the previous studies did not attempt to identify potential English language gains specifically from academic, social, leisure activities and part-time jobs in English; fifth, the study done in Indonesia was carried out quan- titatively by using questionnaires to high school students in which it did not show deep understanding on what the learners really did with their out-of-class activities that the researcher himself admitted the limitations.

Therefore, it is important to explore out-of-class general activities and out-of-class English learning activities done by the English students in an EFL context since in an EFL context, students rarely encounter to the native speakers. Identifying what activities students make use of with many available options outside the classroom and how these activities become meaningful for the improvement of their English will be helpful for understanding the differences of the achievements of the English Department students through this study.

To explore the out-of-class activities and out-ofclass English Learning activities employed by the students of the English Department, the following question is formulated.

How do out-of-class activities employed by the successful and unsuccessful students of the English Department lead to the variability of their achievements and their proficiency at the English Departments?

To answer this key question, two subordinate questions are formulated: (1) How are out-of-class general activities employed by the successful and unsuccessful students of the English Department?; (2) How are out-of-class English learning activities employed by the successful and unsuccessful students of the English Department?

\section{METHOD}

This study is qualitative in nature. The data of this study are concerned with the out-of-class activities employed by the successful and unsuccessful students. In order to find out what out-of-class general activities and out-of-class English learning activities that lead to the variability in the English achievement, English Department students are chosen as the participants. The students are classified into two groups: successful and unsuccessful students. This classification is made in order to see how out-ofclass general activities and out-of-class English learning activities play a role in the English Department students' achievement and how these activities lead to the variability in the students' academic performance and their English proficiency.

In order to get more complete data about outof-class general activities and out-of-class English 
learning activities, the research is also done on the students of the English Department of Lambung Mangkurat University, since different atmosphere, such as different climate, facitilities, opportunities to use English and environment that supports and motivates, such as the people's attitudes toward them studying at universities and so on, can lead to more comprehensive understanding.

It uses a case-study approach in exploring the out-of-class general activities and the out-of-class English learning activities of the successful students and the unsuccessful students of the English Departments that lead to the variability of their English achievement and their proficiency. The case study selected to approach the data not due to the number of the subjects involved but the out-of-class activities employed by the students so that they lead them to achievement and proficiency. To explore the activities, the researcher carried out the study by interviewing at length the selected participants. In order to get the answers of the research problems, this study was done through two stages. The first stage, the preliminary stage, was selecting the participants and the second stage, the main stage, was interviewing the participants in-depth.

To collect accurate information, the participants were interviewed in depth for a few times. The oneto-one interviews were conducted with the participants in different times. Other people, such as: classmates, roommates, and sisters who were assumed playing important roles in their English learning activities were also interviewed.

In order to get the answer of the research question, the study was done through (1) documents analysis from the academic records of S-1 SNMPTN students registered in the academic year 2010/2011 to select the participants, (2) in-depth interviews with the participants which were done one by one. This research has six successful participants (4 females and 2 males) and three unsuccessful participants (one female and two males). They are selected based on their Grade Point Average of their language skills and content courses they took at the English Department. The interviews were done in Malang and in Banjarmasin. The data analysis was done through three stages: (1) writing the transcripts of the recorded data, (2) doing data reduction by selecting, simplifying, focusing, summarizing, and sorting, (3) analyzing and classifying the data using the categories used in this study, (4) drawing conclusions. The data analysis was done during the data collection process and after the data colletion sessions were completed.

\section{RESULTS}

The findings show that (1) all successful participants employ their academic activities as their main general activities in every possible time, while the unsuccessful ones do not employ them intensively; (2) successful participants do social activities by helping others with English, while the unsuccessful participant is actively participate in a students' asscociation as a vicechairman which does not need him to use; (3) the out-of-class general activities of the successful participants are mostly academic activities and part-time jobs, while the out-of-class general activities of the unsuccessful students are mostly social activities by participating in students' association, and leisure activities, such as: watching movies, browsing the internet, and reading novels; (4) if the successful participants have time for leisure activities, they like reading, browsing the internet for reading English materials and watching English movies, while the unsuccessful participants like watching movies and TV programs, playing games, browsing the internet and hanging out with their friends; (5) most of the successful participants have part-time jobs as English teachers, while some of the unsuccessful participants, who have jobs, have their own businesses (not involving English); (6) almost all successful participants except one participant implement Self-Instruction in their part-time jobs as English teachers, while two unsuccessful ones almost do not implement it at all in their out-of-class activities; (7) successful participants implement Naturalistic Language learning more than the unsuccessful ones. They employ it in their academic activities (studying and reviewing their lessons) and in their leisure activities (watching western movies, reading English novels, and listening to songs). If successful participants spend more for their academic activities than their leisure activities, the unsuccessful participants spend more on leisure activities than their academic activities; (11) some successful participants implement Self-Directed Naturalistic Language Learning by visiting ESAC, writing diaries, sending English messages, reading newspapers, thinking in English and speaking it out loud she just watches but none of the unsuccessful participants do. 


\section{DISCUSSIONS}

\section{Out-of-Class Activities among the Students of the English Department}

Students choose and decide their out-of-class activities based on what they like to do and what they need. Every student has his or her own activities. It cannot be generalized that all successful students do academic activities like studying and reviewing regularly. Although they do their academic activities, it does not mean that they all do the activities in a similar way with how they do them, because they also have other activities as indicated by the finding that all successful participants do their academic activities.

Based on the findings of the study, all students do academic activities and leisure activities, but they show differences in the intensity of the activities. Successful students usually do academic activities intensively and they always try to find opportunities to do them. They often skip their leisure activities and parttime jobs, so that they can do the academic activities. They always try to do their best with their assignments, and they make themselves sure that they learn something from their assignments.

However, it should be noted that the English Department students are mostly assigned group-assignments. Therefore, they usually distribute their assignments among the members of their groups. In this situation, some of them prefer to do all the assignments because they want to know everything, while some others especially the unsuccessful ones want to do just the parts they are assigned. It implies that the assignments only benefit the successful students who like to learn everything but not the other students who only like to do their parts. The students who do only their parts assigned by the group, limit their opportunity not only to a small portion of knowledge but also to a limited exposure to English. Exposure to English enables them to improve their ability to use the English language and eventually becomes more proficient (Magno, 2004).

The successful students always try to find time to do their assignments and study whenever possible. They also show that they try to do their best in order to get their good academic achievement. This implies that the successful students use their efforts in doing out-of class academic assignments, such as preparing their presentations, writing their reports, and studying. Their efforts are in the form of out-of-class academic activities. These efforts show that they are willing to study and they have motivation. This is supported by
Cotterall (1999) in her study that motivation can lead to successful autonomous learning.

It is found that all successful participants have a different schedule for doing their academic activities, because of their busy activities. they do not have a certain regular schedules for studying and reviewing. They just do the activities whenever possible because of their classes, the assignments and the jobs they have to do, so that not all of them study and review their lessons regularly.

As seen from what and how they do their outof-class activities, the successful students feel responsible for their assignments. None is interested in participating in organizations in their last semesters and doing other activities except doing their part-time jobs. Since they get many assignments from many classes they take, two of the successful students have to decrease the time they spend in their private English courses. It is noted that not all successful participants quit their jobs when they are at their sixth and seventh semester, because they say that they have to earn some money to pay for their daily needs. One participant also has to stop teaching and to skip from joining a gym because of the assignments he gets. This is consistent with Gardner (2001) who says that a motivated individual makes an effort to study that can be seen that he/she does their assignments, finds opportunities to read their reading materials, and so on. In other words, the out-of-class activities employ indicate the students' efforts and how motivated the students are.

Also, the out-of-class activities also show how the successful students are hard-working. Besides giving private English courses, some of them also have other routine social activities such as teaching religion, volunteering teaching children in their neighborhood or children from a village, and getting together with their friends. Having many activities and doing their part-time jobs make them try hard to find opportunities to do their assignments, such as waking up very early or bringing their books everywhere they go or when their students do not want to study.

In addition, successful students have targets of achievement. Most of them like to have the best scores and the others like to perform well in front of their friends and their lecturers. Because they do not want to embarrass themselves, they work hard to prepare by studying what they are going to present. This is in line with Harmer (2007) who mentions goal orientation as one factor of good learning. 
The unsuccessful students also do academic activities. As discovered in the study, the unsuccessful students do their assignments and also study. But, because their social and leisure activities waste much of their time, they cannot study their lessons and do their assignments well. They also have to wait for their friends to help them do their assignments, since their English does not sufficiently facilitate them to do their assignments on their own. This shows that they are dependent students. This is in line with Little (2009) who emphasizes that if learners become more autonomous in language learning, their language use will escalate. Consequently, the unsuccessful students could not perfrom well with their achievement and proficiency. This also implies that the unsuccessful students do not have the confidence and ability to do their own academic assignments, such as preparing their presentations, writing their reports, and studying. From this situation, it also indicates that they do not have a strong motivation to solve their problems with English and that they are dependent on others.

It is found that all unsuccessful participants do not study regularly. They just study whenever they like, so that they do not learn much from their outof-class academic activities. Also, the unsuccessful students do not do their best concerning with their out-of-class activities in order to get the best results, although all of them like to pass the courses.

It looks like the problems of the academic activities come from the students themselves. One unsuccessful participant, for example, has two problems that hinder him to get high achievement. The first problem is that he knows well that he enjoys sleeping much. He spends much time for sleeping. However, he indicates that he sometimes can manage his sleeping time if he wants. But, he often allows himself to spend a very long time to sleep, rather than spending it for studying. The second problem he has is that he is very active in a student organization since he is the vice chairman of the organization. He goes to the office after his classes every day. He even sometimes spends the night at the office. The other unsuccessful male participant really likes playing with the internet. If he does not have classes, he spends his time browsing and downloading novels or comics he likes reading. Unfortunately, they are mostly in Indonesian. His other problem is that he does not like studying at the English Department because he does not like the courses, so that he does not like to study seriously and does not want to get tired because of studying. He only wants to study if he has to give oral presentation in his class.
The other unsuccessful female participant also has personal problems. She has a small child that she has to take care of. Although she says that her child does not disturb her when she has to study, the situation still makes her unable to concentrate fully on her academic activities. Moreover, she knows that she needs to have better English than she has now but she admits that she does not try hard to study English. She already has the books and the internet to look for references to improve her knowledge and English skills, but she does not take opportunity to study because she says that she does not have time and she never completes her exercises. But, she watches movies every day, and does not like to skip the program because she likes the stories.

Moreover, they still do their leisure activities, even when they get many assignments from many classes they take. They do not want to leave their hobbies. The four unsuccessful students can be categorized as low-motivated students because they do not show that they try hard to study. This is also consistent with Gardner (2001) who says that a motivated individual makes an effort to study that can be seen that he/she does their assignments, finds opportunities to read their reading materials, and so on.

Unlike the successful students, the unsuccessful students only like to pass their courses, they do not aim at having best-scores of achievement. One of them sometimes studies hard when he has to perform, because he does not want to embarrass himself. This is also in line with Harmer (2007) who mentions goal orientation as one factor of good learning. This is also supported by Schunk (2001) that students motivated to attain a goal engage in self-regulated activities they believe will help them. In turn, self-regulation promotes learning and perception of greater competence sustains motivation and self-regulation to attain new goals.

In the mean time, all unsuccessful participants also do academic activities and leisure activities, but they do the academic activities when they feel they like. Usually they do them after they are done with other activities. This indicates that they only have limited time for doing their academic activities. It is also noted that the unsuccessful students are dependent on their friends when they do their assignments. Most of them always ask their friends about the assignments. They even admit that they are not very confident with their English, so they often ask their friends to check their English. Unlike successful students, they also do not like to leave their other activities, such as: their hobbies and their social activities. 
Moreover, although unsuccessful students have many academic assignments, they still look for opportunities to do their hobbies, such as watching movies while they are in their meals, browsing or reading through the internet while waiting for their students work on their exercises or when the children do not want to study, etc. Moreover, they do their assignments with their best efforts to get the best result, while the unsuccessful do their assignments in order to pass the subjects.

The other finding shows that almost all successful participants have social activities for helping others with their English. Besides academic activities, most of them also have social activities. These activities cannot be avoided because human beings are social creature in order to live in harmony with other people around them. It happens because they have the ability to be shared with and the people expect them to do so. However, not all successful participants have social activities.

It is also found that not all successful participants employ social activities involving English. Most of the successful students share their English skills they have with others who need them, such as helping them doing their English homework, translation and even pronunciation. By doing this, the successful students employ Self-Instruction because they need to prepare their teaching activities by learning before or when they work with them. This indicates that the students fulfill one of the goals of the English Education Study Program that students can implement continuous independent learning to achieve and develop new knowledge and skills (Katalog Jurusan Bahasa Inggris, 2010, p. 12).

In contrast, only one unsuccessful students employed social activities. If the successful students mostly use English when they do social activities, the unsuccessful student has social activities with no English learning. The personality and the family situation might be the reasons why students like to be active in an organization. He has many friends that he likes to get together with. The other two unsuccessful participant do not like to employ social activities. One of them does not have many friends. He likes to be by himself. It can be seen from the few friends he has and he usually gets together with. Another has to take care of her family so that she does not have time for social activities.

The findings of this study, concerning leisure activities, show that successful students also employ leisure activities, but they have limited time for doing them. They like doing their leisure activities with English. But, although they do various activities, only for a few minutes, they do not get much English from them. The students do not try to do English learning activities much, and thus does not follow Macaro's suggestions (2001) about making the activities into the habits of looking for the foreign language outside the classroom.

Meanwhile, the unsuccessful students have more leisure activities than academic activities. They have different kinds of leisure activities, but they do them regularly every day. They like to play games, watching $\mathrm{TV}$, using the internet, and hanging out with their friends as their leisure activities. but, most of all activities are in Indonesian. They also like to listen to songs in their leisure time but very seldom studying the lyrics. One unsuccessful participant likes to do his own hobbies every day, browsing and reading the materials from the internet. Ar likes to watch movies and to listen to songs. Thus, they spend much of their out-of-class time more for doing unacademic work, which actually should be spent more on improving their knowledge and English skills in order to get a higher achievement. They do not take opportunities to improve themselves even from the activities they like to do. This study is almost similar with what Hashemi, Ershadi, and Hamidi (2013) study that students' leisure time are mostly spent on watching television, working with computer, listening to music, hanging out with friends and doing sport.

The next finding shows that not all successful participants have part-time jobs. Most of the successful participants give private English courses as their part-time jobs. Only two successful participants do their part-time jobs regularly. They do these activities because they need to support their livings, to pay for their daily needs. Therefore, they cannot just leave the activities. On the other hand, the other successful participants leave their part-time jobs when they are at the sixth and seventh semester, because they need more time to do their academic work.

Meanwhile, the finding also shows that not all unsuccessful students have part-time jobs. In fact, two of them have businesses of their own. One unsuccessful participant likes to buy and sell used scooters, while another has an online-business. She sells clothes and chocolates. In fact, it is good if the students are able to earn money for themselves, but, it would be better if the activities did not cause them to neglect doing their academic work.

Only successful students work intensively, the unsuccessful students do not, although with different 
schedules because of their other activities. As also shown by one of the findings of this study that the unsuccessful students do their leisure activities and social activities (if any) more than academic activities. All students have leisure activities. But, the activities are different in the length of time and in the kinds of leisure activities they do. Successful students have limited time for leisure activities except one successful participant who cannot leave his reading activities. The unsuccessful students have more time for the activities as it is shown in the study that they do their hobbies regularly: watching movies and tv programs and browsing and downloading using the internet.

It can be concluded that all students have different out-of-class activities. They do not do all kinds of out-of-class activities: academic, social, leisure activities and part-time jobs. Even if they do the activities, they are not done regularly. Also, it can be concluded that the students have different out-of-class activities because of different reasons coming from themselves.

The decisions of what the students do in fact come from the students themselves. They should decide to prioritize academic activities among other activities when they are students. Some participants have shown that they still have good achievement although they do other activities. They can manage their time for studying and other activities well. Therefore, to sum up in order to be successful students should decide to prioritize the academic activities among other activities by well-managing their time and activities. At the same time, it is indicated that relevant out-of-class activities with their field of study, like giving English private courses, benefit them in getting high achievement and high proficiency.

It is also found in the study that all successful students prioritize out-of-class academic activities to other general activities, while the unsuccessful students spend their out-of-class time for other general activities, such as social, leisure activities, part-time jobs more than academic activities. The successful students prioritize their academic activities than other activities. They can manage their out-of-class time well so that they can do their academic activities to achieve their academic achievement goals they set, while the unsuccessful students prioritize their leisure and social activities. In short, priotizing out-of-class academic activities to other general activities leads the students to high achievement.

\section{Out-of-Class English Learning Activities in Out-of-Class General Activities of the English Department Students}

The findings of this study show that successful students employ more English learning activities in their general activities than unsuccessful students. In this study, the out-of-class activities are categorized into general activities and English Learning activities. The students' general activities can be academic activities, social activities, leisure activities and part-time jobs. The English learning activities are identified among the students' general activities. These English learning activities are categorized into Self-Instruction, Naturalistic Language Learning, and Self-Directed Naturalistic Language Learning.

As it is also shown by the findings, not all students, even successful students, employ all the categories of English Learning. All successful students employ Self-Instruction in their limited time. Some of them say that they do not have time to do that, and they add that they are not studying English, but they are using English as a means of communication. They use English during the lectures in their classrooms, and they also need English when they study their lessons and do their English assignments.

It is noted that all successful participants employ Self-Instruction for different purposes. Self-Instruction is employed when they prepare for what they have to teach. In order to explain well, they need to study first before they give private courses. Most of them admit that they have to prepare so that they can help their students with their complicated grammar. Self-instruction is also employed when they do social activities. Most of them help high school students, undergraducate and graduate students. Most of them need their help mostly with grammar and translation. Most successful students who teach as their part-time jobs employ Self-Instruction mostly for English grammar they have to teach, especially when they teach complicated English structures. Thus, these activities benefit them in their English learning although they are mostly for English grammar. To sum up, some successful students employ Self-Instruction in their social activities, part-time jobs and in their leisure time, such as on weekends and during the semester breaks because they feel they lack some English skills, such as listening and pronunciation.

Like successful students, all unsuccessful students also do not employ all categories of English 
Learning. They do not show that they employ SelfInstruction from their out-of-class academic activities during the fifth and sixth semesters. They employ SelfInstruction when they have leisure activities, for example when they play games because they look for some English words for the games.

This is obvious from the way Gs does when he plays games. He uses an English-English dictionary when he plays games, because he needs to know the English words and the meanings when he plays word puzzles and when he has to follow the instruction. $\mathrm{He}$ admits that he often opens the dictionary while he is playing. But, he plays only for sometime before he goes to bed or when he is alone at his boarding house. However, this situation seldom occurs because he prefers to go out to UKM and gets together with his friends. In addition, there is not much English that can be learned from playing games. The narrators use the same instructions again and again as he admits, and they only get isolated words that are rather difficult and many of the words are uncommon to use in communication. As a result, he does not get much English from those leisure activities he likes to do.

Another unsuccessful student, Ar, employs SelfInstruction when she helps Elementary school students with their English homework. Most of the students only get some basic high-frequency words and some basic sentence structures. It implies that she does not get much English from the activities, since she already knows well most of the words and the sentence structures. In other words, the Self-Instruction employed by the unsuccessful students are not meaningful for improving their English. Their social activities and parttime jobs do not require them to use English. As a result, they do not take the opportunity to expose themselves to English from the activities.

The next finding shows that all students employ Naturalistic Language Learning in their academic activities and their leisure activities. This category of language learning is applied since the assignments are read and written in English. Employing Naturalistic Language Learning means that the students learn English subconsciously when they have academic and leisure activities. Therefore, all students employ this Naturalistic Language Learning for their reading and writing activities.

One of the successful students does her academic activities by retelling or speaking out what she has studied in order to understand the concepts better. She creates the context or situation in order to get the knowledge and at the same time she also improves her oral English. Doing these activities, she also exposes herself to oral English. But, not all students do this. The students who work (especially read) well on their academic work themselves show better achievement and better English Proficiency Scores than those who do not spend much time studying (See Appendix 7,p.173).

By doing the academic activities as discussed above, they will get opportunity to use and develop their English. It means the more English assignments they get the more they will have the opportunity to be exposed to English. The more exposure the students have, the more proficient they will be. This is stated by Harmer (2007) that English students need to have much exposure to English. He says that exposure to the language is essential to language acquisition. Students can have rich exposure by having a lot of out-of-class activities that give them a lot of opportunities to use English. Having rich exposure to English through their out-of-class activities might as well contribute to their achievement.

Unfortunately, some of the successful students do not spend much time reading for studying to get a broader understanding; they mostly spend much of their time doing the assignments and just study the reading materials they are given. Therefore, they do not get much exposure to English. This can be seen from most successful students who do not do much reading from their assignments and their leisure activities, their proficiency scores (See appendix 7, p. 173) are not more than 550 as expected in the English Education Study Program Aims (Katalog Jurusan Bahasa Inggris, 2010, p. 12).

Unlike the successful students, the unsuccessful students do their academic activities in a limited time after they do their other activities, so that they neither have many opportunities to study their lessons thoroughly, nor they do not get many opportunity to employ Naturalistic Language Learning to improve their reading and writing skills. It is also noted that all unsuccessful participants depend on their friends when they do their assignments, while the successful participants are independent and like to do everything by themselves. The successful students read their reading materials and write reports or presentations assigned by their lecturers. These activities expose the successful students more to English. As stated by Leaver, et al (2005) the kinds of things that students do independently can do much to improve their language learning. Successful language learners acquire much English if they study, review and do their as- 
signments well by themselves. This is in line with what Bawawi (2002) stated that extensive reading has been shown to be a single best thing that one can do to improve general foreign-language proficiency.

Moreover, the unsuccessful students are not confident with their English. Therefore, they feel that they need to ask their friends. This can also be seen from the interviews with them, they asked to be interviewed in Indonesian. This means that they do not feel comfortable talking in English. That is because they believe that their English does not facilitate them to communicate well.

Naturalistic Language Learning is also employed in leisure activities by all students. Successful students do not have much time for leisure activities because they are already busy with their academic activities and part-time jobs, while the unsuccessful students are busy with their non academic activities. It is found from the study that all successful participants have limited time for leisure activities. If they have, their leisure activities are reading any kind of reading materials, watching movies and TV programs, and using the internet. Meanwhile, the unsuccessful participants like to play games, watching TV, using the internet, hanging out with their friends and listening to songs as their leisure activities. These kinds of activities are almost similar with the findings of the study by Spratt, Humphreys, and Chan (2002) who discovered that most activities adult learners engaged in are watching movies and television in English and using the internet. In addition, Hyland (2004) showed that some of the activities students do in English are reading novels, reading newspapers, and magazines, watching TV programs, watching videos, surfing the internet, and reading academic books

Unfortunately, in terms of the intensity of the activities done in the study, it is noted that successful students have low intensity in doing their out-of-class leisure activities, while the unsuccessful students have more time doing leisure activities, but they do not take many opportunities to improve their English from the activities, because they get limited opportunity to expose themselves to English. Moreover, all students are not aware that they can quickly improve their English fast through their leisure activities. Students of the English Department should find meaningful leisure activities that benefit them as the students of the English Department.
Everybody needs leisure activities in order to feel rejuvenated to do their main activities. English Department students should feel obliged to always improve their English. By doing English leisure activities they can expose themselves to English. They can choose English movies and English TV programs, English newspapers, and the English articles from the internet. They should be aware that they are surrounded by English-rich environment. English TV programs, English newpapers and magazines, English books, and internet are now easy to find and to access. Students can acquire English from leisure activities while they are relaxing, besides their academic activities.

As shown by the findings of the study, all successful students, except one participant, employ Self-Directed Naturalistic Language Learning. If students employ this category, they show that they have great motivation to improve their English skills. The findings show that most of the successful students employ it to improve their speaking and writing skills. Besides those two productive skills, they also practice to use the right vocabulary, grammar, and listening.

The successful students employ Self-Directed Naturalistic Language Learning in their Leisure activities. They have different ways when they employ this category. One goes to ESAC with the purpose of having English communication with her friends and the staff there. She goes there every day. One writes diaries to practice writing and using the right vocabulary and grammar. She also listens to songs and writes their lyrics to practice her listening. One sends English messages to his friends so that he can practice writing. One watches movies and retells and acts out the stories. She also communicates in English to her sister every day. One forces himself to think in English. After sometime he is able to speak out loud automatically what he thinks. So, the students who employ, create or find natural situations will help improve their English.

Their Self-Directed Naturalistic Language Learning ways are really effective for them. They can improve their English because of employing this category. Ro likes watching cartoon movies. She often finds and watches the movies with her younger sister to practice her English. She does not only listen but she also imitates the expressions. Also, she often asks her sister to act the stories out with her to practice English. Therefore, both of them can communicate in English.

Another situation she creates is using English as their means of communication. This is in line with what 
Nunan (1999) said that prior experience as a listener helps speaker improve their performance as a speaker. Specifically, being a listener gives her models to deploy when acting as a speaker.

Meanwhile, one participant improves his English through his daily reading activities. He also forces himself to think and to speak out loud what he thinks. $\mathrm{He}$ has done that for six months. He admits that the strategy works for him. Thus, doing their hobbies such as reading, watching movies, and thinking aloud in English, they expose them to English and the activities they do as their hobbies unintentionally and intentionally affect the progress of their English.

All those mentioned above show how successful students give their efforts in learning English. If one of the successful students still have low-proficiency, that might be because of the lack of intensity of Naturalistic Language Learning she employs. In other words, she does not do many activities, such as: reading, speaking, listening or writing in English in her daily activities. This is in accordance with the exposure condition that the more time spent learning any aspect of a second language, the more will be learned (Spolsky, 1989). How well the students' proficiencies and their achievements can be seen in the Appendix 7 (p.173). The students admit that by doing the activities they are successful in improving their English.

The findings of this study indicate that by having Naturalistic Language Learning in their leisure activities, students are not only successful in their academic achievement at the English Department, but they also get high scores from their English proficiency tests. This is in line with the study done by Green and Oxford (1995) which show a positive correlation between the out-of-class activities and their English achievement, such as: reading for pleasure has a high correlation with overall language proficiency. This is also supported by Renandya's (2007) about extensive reading that shows that exposure to free reading gives significant growth in reading comprehension, word recognition and oral sentence repetition. Similarly, Ucan (2010) shows that extensive listening is highly beneficial to students' English improvement.

The finding of this study also shows that the successful students of the English Department employ out-of-class English learning activities more than the unsuccessful students. This finding is in line with the finding of the studies done by Lamb (2004) and Marefat and Barbari (2009) who suggested that the high-achieving group tend to employ out-of-class language learning more than those in mid or low a- chieving group in their study about out- of-class language learning across three different proficiency levels (high, mid, and low-achieving students).

It is also noted that the successful students like to use their out-of-class leisure activities involving English, while the unsuccessful students do not. This situation occurs because the successful students have the ability to do their activities, while the unsuccessful students do not have enough English to do their leisure activities involving English. The successful students like reading English magazines, watching English TV program, and browsing English books from the internet. Like admitted by Gs who is categorized as unsuccessful, he likes using a dictionary when he plays games. This is in accordance with the finding of the study done by Pearson (2004) that activities that do not require students to understand English such as using dictionaries, are chosen mostly by low-achieving group. On the other hand, the use of authentic materials such as magazines, novels, newspaper seems to be favored more by high-achieving group.

This indicates that English is needed for doing out-of-class activities involving English. Successful students have the ability to comprehend authentic reading materials that might be too difficult for unsuccessful students. This implies that the more out-ofclass activities using English, the higher the English proficiency of the students.

Employing many English learning activities leads the students to high English proficiency and high English achievement. Exposure to English enables them to improve their ability to use the English language and eventually they become more proficient. (Magno, 2004). This is also in line with Spolsky's (1989) that the outcome of language learning depends in large measure on the amount and kind of exposure to the target language. Thus, the most possible activities in which the students can expose themselves to English are mostly from the academic activities, and their English leisure activities. They always do these two activities as students, but not social activities and parttime jobs.

The findings also show that successful participants do social activities which involve their English learning, while the unsuccessful participant do social activities with no English learning. This indicates that the unsuccessful students do not look for opportunities to have English learning activities. These social activities and part-time jobs will support the students in getting high achievement and proficiency if the activities are related to their field of study, for example giving 
English private courses, being an English radio announcer, or being an English magazine editor, and so on.

Therefore, students of the English Department should take advantage of the assignments given by the lecturers and the English leisure activities they have. They should be aware that through those activities they can expose themselves to English, besides getting the knowledge. Then, the most important factor relating to these out-of-class activities, consisting of general activities and English learning activities is the students as the ones who decide what and how the activities are done. They choose the right activities, and do them to make them not only useful for their achievement but also for their English proficiency.

\section{CONCLUSIONS}

It is concluded that every student of the English Department employs out-of-class activities differently. The activities consist of general activities and English learning activities. The general activities, written in order, most successful students employ are academic, part-time jobs, leisure activities and social activities, while the English learning activities employed are Naturalistic Language Learning, Self-Directed Naturalistic Language Learning, and Self-Instruction.

Meanwhile, the general activities most unsuccessful students do are leisure activities, part-time jobs, social activities and academic activities, while the English learning activities they employ are Naturalistic Language Learning, and Self-Instruction. It should be noted that although the categories are mentioned for the successful students and unsuccessful students, they are still different in intensity among the individuals.

Therefore, because the students employ different out-of-class activities, their achievements and their English proficiency are different. Also, students decide, choose and do what they feel they like to do for their out-of-class activities. They should prioritize and optimize their academic activities more than other academic activities. In other words, students get low achievement because of their bad decision concerning their out-of-class activities. As students of the English Department they should motivate themselves to find opportunities in their out-of-class activities to expose themselves to English, so that they do not only have high proficiency but they also have high English achievement, because good English proficiency will help them follow their courses at the department. In a nutshell, employing many English learning activities leads the students to high English achievement and high English proficiency.

It is suggested English Department students should select, manage and do the right out-of-class activities that are relevant with their field-of-study, and that could accelerate their achievement and their English proficiency, which prioritize, and optimize their academic activities among their other activities. English Department lecturers should give motivation and facilitate the students by giving assignments that give opportunities for students to employ English learning activities, especially when they are at their last semesters since the courses offered are mostly not about English skills so that they do not have much English practice to maintain and improve their English. Lecturers or academic advisors should spend some time to find out if their unsuccessful students use their time wisely.

\section{REFERENCES}

Anderson, N.J. (2009). Metacognition and Good Language Learners. In Griffiths C. (Ed.) Lessons from Good Language Learners. pp. 99-109. UK: Cambridge University Press.

Astin, A. W. (1993). What Matters in College: Four Critical Years Revisited. San Francisco: Jossey-Bass.

Benson, P. (2001). Teaching and Researching Autonomy in Language Learning. London: Longman Inc.

Benson, P. \& Nunan, D. (Eds). (2004). Learners'Stories: Differences and Diversity in Language Learning. Cambridge: Cambridge University Press.

Bown, J. (2006). Locus of Learning and Affective Strategy Use: Two Factors Affecting Success in Self-Instructed Language Learning. Foreign Language Annals, 39(4), 640-659.

Brooks, F. B. (1992). Communicative Competence and the Conversation Course: A social Interaction Perspective. Linguistics and Education, 4(2), 219-246.

Brown, H. D. (2001). Teaching by Principles: An Interactive Approach to Language Pedagogy. Second Edition. White Plains, NY: Pearson Education.

Castro, O. and Peck, V. (2005). Learning Styles and Foreign Language Difficulties. Foreign Language Annals, 38(3), 401-409.

Chandrasegaran, A. (1981). Problems of Learning English as a Second Language. Monograph Series of SEA$M E O R E L C$. Edited by Richard B. Noss. Singapore: Singapore University Press. 
Christison, M.A. (2003). Learning Styles and Strategies. In Nunan, D. (Ed.), Practical English Language Teaching (pp. 267-288). Singapore: McGraw Hill.

Cotterall, S. (1999). Key Variables in Language Learning: What do Learners Believe about them?, System, 27, 493-513.

Cotterall. S. (2009). Autonomy and Good Language Learners. In Griffiths C. (Ed.) Lessons from Good Language Learners. pp. 110-119. UK: Cambridge Univerrsity Press.

Diaz, A.Z., (2002). Personal Family, and Academic Factors Affecting Low Achievement in Secondary School. Accessed on May 14, 2010.

Dornyei, Z. (2009). Individual Differences: Interplay of Learner Characteristics and Learning Environment. Language Learning. 59 (SUPP/1): 220-248.

Ellis, R. (2001). The Study of Second Language Acquisition. Eighth edition. Oxford: Oxford University Press.

Evans, L.M. and Kritsonis, W.A. (2008). Reflections on a National Crisis: Student Academic Achievement Gap. National Focus, 24(3).

Fakultas Sastra Universitas Negeri Malang. (2010). Katalog Jurusan Sastra Inggris. Malang: Fakultas Sastra Universitas Negeri Malang.

Fathman, A.K. (1976). Variables Affecting the Successful Learning of English as a Second Language. TESOL Quarterly, 10(4), 433-444. Retrieved from http:// www.jstor.org/stable/3585524.

Field, J. (2007). Looking Outwards, Not Inwards. ELT Journal, 61(1), 30-38.

Firth, A. and Wagner, J. (2007). Second/Foreign Language Learning as a Social Accomplishment: Elaborations on a Reconceptualized SLA. The Modern Language Journal, 91, 800-819.

Fraenkel, J.R. and Wallen, N.E. (2006). How to Design and Evaluate Research in Education. 6th Ed. New York, NY:McGraw Hill

Freeman, M. (1999). The Language Learning Activities of Students of EFL and French at Two Universities. Language Learning Journal, 19, 80-88.

Gardner R.C. (2001). Integrative Motivation and Second Language Acquisition. In Z. Dornyei \& R. Schmidt. Eds. Motivation and Second Language Acquisition. 1-20. Honolulu: University of Hawaii Press.

Green, J., \& Oxford, R. (1995). A Closer Look at Learning Strategies, L2 Proficiency, and Gender. TESOL Quarterly, 29(2), 261-297. http://dx.doi.org/10.2307/ 3587625

Griffith, C.(Ed.) (2009). Lessons from Good Language Learners. Reprinted. Cambridge: Cambridge University Press.
Guofang L. (2007). Home Environment and Second Language Acquisition: the Importance of Family Capital. British Journal of Sociology of Education, 28(3), 285-299.

Harmer, J. (2007). The Practice of English Language Teaching. 3rdEd. UK: Longman. www.longman.com.

Hashemi, Ershadi and Hamidi. 2013. Leisure Time Spending Way by the Students of Bushehr Islamic Azad University with a Focus on Sport Activities. MiddleEast Journal of Scientific Research, 14(10), 12521256.

Hismanoglu, M. (2000). Language Learning Strategies in Foreign Language Learning and Teaching. The Internet TESL Journal,6(8).

Hyland, F. (2004). Learning Autonomously: Contextualizing Out-of-Class English Language Learning. Language Awareness, 13(3), 180-202.

Johnson, B. and Christensen, L., (2000). Educational Research: Quantitative, Qualitative and Mixed Approaches. USA: Sage Publications, Ltd.

Lamb, M. (2004). 'It Depends on the Students themselves': Independent Language Learning at an Indonesian State School. Language, Culture and Curriculum 17(3), 229-245.

Leaver, E., and Shekhtman. (2005). Achieving Success in Second Language Acquisition. USA: Cambridge University Press.

Macaro, E. (2001). Learning Strategies in Foreign and Second Language Classroom. London and New York: Continuum.

Magno, C., Filho, M.K.C., Lajon, J.A. Regodon, J.R. and Bunagan, K.S. (2009). Assessing the Level of English Language Exposure of Taiwanese College Students in Taiwan and the Philippines. The Asian EFL Journal Quarterly, 11(1), 62-73.

Marefat, F. and Barbari F., (2009). The Relationship between Out-of-Class Language Learning Strategy Use and Reading Comprehension Ability. Porta Linguarium, 12,91-106.

Murray, B. (2010). Students' Language Learning Strategy Use and Achievement inthe Korean as a Foreign Language Classroom. Foreign Language Annals, 43(4), 624-634.

Nunan, D. (1999). Second Language Teaching and Learning. Boston, Ma.: Heinle and Heinle Publishers0.

Oxford, R.L., Park Oh Y., Ito S., and Sumrall M. (1993). Factors Affecting Achievement in a Satellite Delivered Japanese Language Program. American Journal of Distance Education, 7(1), 10 - 25.

Papanastasiou, C. (2000). Internal and External Factors Affecting Achievement in Mathematics: Some Find- 
ings from TIMSS. Studies in Educational Evaluation, 26(1), 1-7

Pearson, N. (2004). The Idiosyncrasies of Out-of-Class Language Learning: A Study of Mainland Chinese Students Studying English at Tertiary Level in New Zealand. In Hayo Reinders, Helen Andersson, Moira Hobbs \& John Jones-Parry (eds.), Supporting Independent Learning in the 21st Century: Proceedings of the Inaugural Conference on the Independent Learning Association, Melbourne, Australia, 13-14 September 2003. http://independentlearning. org/ILA/ila03/ila=3_pearson.pdf.

Pickard, N. (1996). Out-of -Class Language Learning Strategies. ELT Journal, 50(2), 150-159.

Rubin, J. (1975). What the Good Language Learner can Teach us. TESOL Quarterly, 9, 41-51.

Saville-Troike.M. (2006). Introducing Second Language Acquisition. New York: Cambridge University Press.

Schunk, D.H. (2001). Social Cognitive Theory and SelfRegulated Learning. In B.J. Zimmerman \& D.H. Schunk (Eds.). Self-Regulated Learning and Academic Achievement: Theoretical Perspectives (pp. 125-153). Lawrence Erlbaum Ass.
Spratt, M., Humphreys, G., \& Chan, V. (2002). Autonomy and Motivation: Which Comes first? Language Teaching Research, 6, 245-266.

Spolsky, B. (1989). Conditions for Second Language Learning. Oxford: Oxford University Press.

Suh, J.S., Wasansomsithi, P., Short, S. and Majid N.A. (1999). Out-of-Class Learning Experiences and Students' Perceptions of their Impact on Conversation Skills. Research Report. Eric Clearinghouse on Language and Linguistics. ERIC Document no. ED433715.

Taguchi, N. (2008). The Role of Learning Environment in the Development of Pragmatic Comprehension: A Comparison of Gains Between EFL and ESL Learner. SSLA, 30, 423-452.

Wenden, A. (2002). Learner Development in Language Learning. Applied Linguistics, 23(1), 32-55.

Yap, S.L. (1998). Out-of-Class Use of English by Secondary School Students in a Hong Kong Anglo-Chinese School (Unpublished MA Thesis). University of Hong Kong, Hong Kong.

Zhengdong G., Humphreys, G., Hamp-Lyons, L. (2004). Understanding Successful and Unsuccessful EFL Students in Chinese Universities. The Modern Language Journal, 88(2), 229-244. 